U.S. DEPARTMENT OF THE INTERIOR

U.S. GEOLOGICAL SURVEY

\title{
CRETACEOUS STRATIGRAPHY IN A NORTHEAST-TRENDING TRANSECT, NORTHERN UTAH TO SOUTH-CENTRAL SOUTH DAKOTA
}

\author{
By
}

E.A. Merewether, J.C. Dolson, W.B. Hanson, W.R. Keefer, B.E. Law, R.E. Mueller, T.A. Ryer, A.C. Smith, D.P. Stilwell, and D.M. Wheeler

Pamphlet to accompany

GEOLOGIC INVESTIGATIONS

MAP I-2609 


\section{INTRODUCTION}

Sedimentary rocks of Cretaceous age at localities along Transect B-B' in Utah, Wyoming, and South Dakota (fig. 1) reflect intermittent deposition and erosion as well as regional and local subsidence and uplift. These former siliciclastic, calcareous, pyroclastic, and carbonaceous sediments accumulated in and adjacent to an epicontinental seaway that occasionally extended from northern Utah eastward to central Iowa and from the Gulf of Mexico northward to the Arctic Ocean. Along the transect, Cretaceous time (65.4-142 Ma; Obradovich, 1993) is represented by eight sequences of beds, which range in age from 65.4 Ma to about 120 Ma (Maastrichtian to Aptian), and by many unconformities.

The Cretaceous stratigraphy for Transect B-B' and three other east-trending transects in the Rocky Mountains and Great Plains was summarized by Dyman and others (1994) for the Western Interior Cretaceous (WIK) Project in the Global Sedimentary Geology Program of the International Union of Geological Sciences. Transect A-A' of the project trends irregularly from southwestern Montana to southwestern Minnesota. Transect C-C' extends from central Utah to northeastern Colorado. The southernmost transect, D-D', trends irregularly from east-central Arizona to westernmost Oklahoma. Dyman and others (1995) subsequently presented a more elaborate description of the rocks in Transect $A-A^{\prime}$. The information originally compiled for Transect B-B' (Dyman and others, 1994) has been supplemented and refined for this publication.

Cretaceous rocks in this transect are depicted on lithostratigraphic and chronostratigraphic cross sections (figs. 2 and 3, respectively) as groups, formations, members, and lithologic units. The rocks of marine origin are classified as sandstone, mudrocks, or carbonate rocks, each of which includes lesser amounts of other rock types. Descriptions of these strata were obtained from studies of outcrops and borehole-records at the following localities, listed from southwest to northeast: Coalville, Utah; Church Butte, Wyoming; Dutch John, Utah; Red Desert, Shotgun Butte, Kaycee, and Red Bird, Wyoming; and White River, South Dakota. The distance from Coalville to White River, along a straight line, is about $580 \mathrm{mi}(930 \mathrm{~km})$. Near the southwestern end of the transect, in the thrust belt and the adjoining foredeep, beds of conglomerate, sandstone, shale, bentonite, and coal were deposited in continental and nearshore marine environments along the western margin of the epeiric sea. Laterally equivalent strata at the northeastern end of the transect on the craton consist of sandstone, shale, limestone, and bentonite that accumulated mainly in shallow-water marine environments. The sequences at the eight localities range in thickness from as much as $18,000 \mathrm{ft}(5,500 \mathrm{~m})$ at the west end of the transect in Utah, to about $3,000 \mathrm{ft}(915 \mathrm{~m})$ at the east end of the transect in South Dakota.

The geochronological framework for Cretaceous strata in the Rocky Mountains and Great Plains (figs. 3 and 4) is based on the identification and correlation of molluscan fossils (Cobban and others, 1994) and palynomorphs (Nichols, 1994) and the determination of radiometric ages (Obradovich, 1993) of associated beds. However, radiometric ages have been established for only 20 of the 73 marine-fossil zones listed in fig. 4; the absolute ages of 53 of the zones have been estimated by extrapolation. The sequences of beds at the localities in the transect (figs. 2 and 3) were correlated mainly by means of distinctive lithologic units, including conspicuous beds of bentonite, and marine molluscan fossils. Chronohorizons depicted on the cross sections indicate the established and estimated stratigraphic locations of marine fossils that represent five of the fossil zones listed on fig. 4. Fossils characteristic of these chronohorizons are widespread and are commonly associated with recognizable stratigraphic units. Fossils typical of other zones commonly are less abundant and are associated with less widely correlative beds. The datum for fig. 2 is fossil-zone 9, Baculites reesidei Elias of late Campanian age.

\section{STRATIGRAPHY}

The Cretaceous sequences at the localities along Transect B-B' range from comparatively thick and dominantly nonmarine in northern Utah to relatively thin and dominantly marine in south-central South Dakota (figs. 1 and 2). Horizontal distances between the localities depicted on figures 1 and 2 during Cretaceous time have not been palinspastically restored. At Coalville, Utah, in the Sevier Orogenic Belt, the rocks are mostly siliciclastic and are as much as $18,000 \mathrm{ft}(5,500 \mathrm{~m})$ thick; they were deposited mainly in continental environments near the western shore of the epicontinental sea. About $82 \mathrm{mi}(132 \mathrm{~km})$ east-northeast of Coalville is Church Butte, situated on the Moxa Arch (figs. 1 and 2), where Cretaceous siliciclastic rocks are about 4,900 ft $(1,500 \mathrm{~m})$ thick. Most of the section preserved there accumulated in marine environments. At Red Desert, in the Cretaceous foreland, about $180 \mathrm{mi}(290 \mathrm{~km})$ east-northeast of Coalville, the strata are as much as $13,000 \mathrm{ft}(4,000 \mathrm{~m})$ thick and are composed of siliciclastic rocks and minor amounts of carbonate rocks that were deposited mostly in marine environments in the western part of the seaway. The Cretaceous sections at the localities north-northwest and northeast of Red Desert (figs. 1 and 2) thin progressively eastward and they consist of marine and continental rocks. At Shotgun Butte, Cretaceous strata are about 


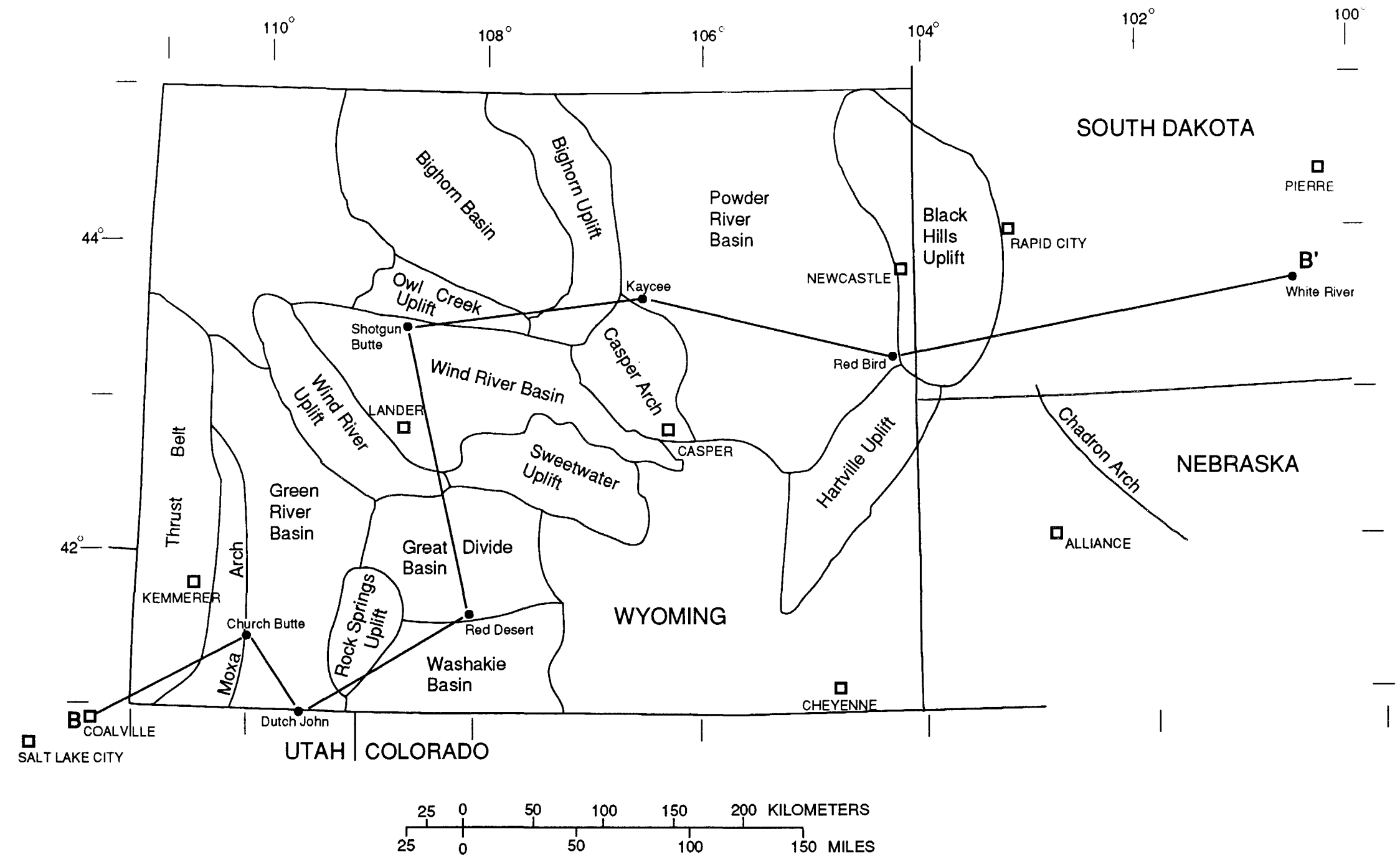

Figure 1. Map showing approximate location of cross section B-B', selected major structural features, and villages and towns in parts of Utah, Wyoming, South Dakota, and Nebraska. 


\begin{tabular}{|c|c|c|c|}
\hline 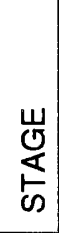 & 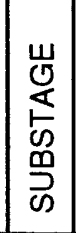 & 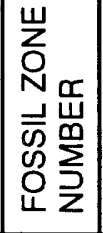 & FOSSIL ZONE \\
\hline 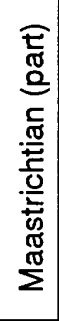 & 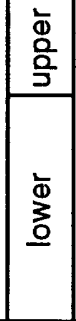 & $\begin{array}{l}1 \\
2 \\
3 \\
4 \\
5 \\
6 \\
7\end{array}$ & $\begin{array}{l}\text { Jeletzkytes nebrascensis } \\
\text { Hoploscaphites nicolleti } \\
\text { Hoploscaphites birkelundi } \\
\text { Baculites clinolobatus * } \\
\text { Baculites grandis } \\
\text { Baculites baculus } \\
\text { Baculites eliasi }\end{array}$ \\
\hline 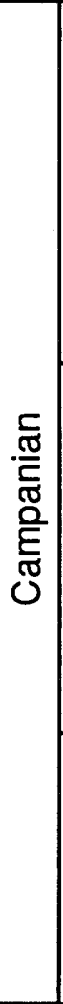 & $\frac{\frac{\Phi}{D}}{\frac{\partial}{E}}$ & $\begin{array}{r}8 \\
9 \\
10 \\
11 \\
12 \\
13 \\
14 \\
15 \\
16 \\
17 \\
18 \\
19 \\
20 \\
21 \\
22 \\
23 \\
24 \\
25 \\
26 \\
27 \\
28 \\
29\end{array}$ & $\begin{array}{l}\text { Baculites jenseni } \\
\text { Baculites reesidei } \\
\text { Baculites cuneatus } \\
\text { Baculites compressus * } \\
\text { Didymoceras cheyennense } \\
\text { Exiteloceras jenneyi * } \\
\text { Didymoceras stevensoni } \\
\text { Didymoceras nebrascense * } \\
\text { Baculites scotti } \\
\text { Baculites reduncus } \\
\text { Baculites gregoryensis } \\
\text { Baculites perplexus } \\
\text { Baculites sp. (smooth) } \\
\text { Baculites asperiformis } \\
\text { Baculites maclearni } \\
\text { Baculites obtusus * } \\
\text { Baculites sp. (weak flank ribs) } \\
\text { Baculites sp. (smooth) } \\
\text { Scaphites hippocrepis III } \\
\text { Scaphites hippocrepis II * } \\
\text { Scaphites hippocrepis I } \\
\text { Scaphites leei III }\end{array}$ \\
\hline 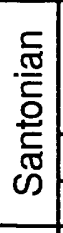 & \begin{tabular}{|c|}
$\bar{ळ}$ \\
윽 \\
mid \\
low \\
\end{tabular} & $\begin{array}{l}30 \\
31 \\
32 \\
33 \\
34\end{array}$ & $\begin{array}{l}\text { Desmoscaphites bassleri } * \\
\text { Desmoscaphites erdmanni } \\
\text { Clioscaphites choteauensis } \\
\text { Clioscaphites vermiformis } \\
\text { Clioscaphites saxitonianus } *\end{array}$ \\
\hline . & \begin{tabular}{|c|}
$\bar{\Phi}$ \\
$\overline{2}$ \\
mid \\
low \\
\end{tabular} & $\begin{array}{l}35 \\
36 \\
37 \\
38\end{array}$ & $\begin{array}{l}\text { Scaphites depressus } \\
\text { Scaphites ventricosus } \\
\text { Cremnoceramus deformis * } \\
\text { Forresteria peruana }\end{array}$ \\
\hline
\end{tabular}

*Fossil-zones dated radiometrically (Obradovich, 1993).

Figure 4. Ages and fossil-zones for marine strata of Cretaceous age in the Western Interior, U.S.A. (Cobban and others, 1994). 


\begin{tabular}{|c|c|c|c|}
\hline 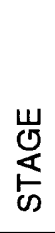 & 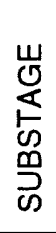 & 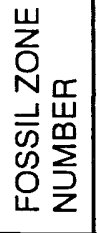 & FOSSIL ZONE \\
\hline 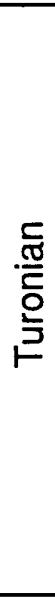 & $\frac{0}{\frac{0}{6}}$ & $\begin{array}{l}39 \\
40 \\
41 \\
42 \\
43 \\
44 \\
45 \\
46 \\
47 \\
48 \\
49 \\
50 \\
51 \\
\end{array}$ & $\begin{array}{l}\text { Prionocyclus germari } \\
\text { Scaphites nigricollensis } \\
\text { Scaphites whitfieldi } \\
\text { Scaphites ferronensis } \\
\text { Scaphites warreni } \\
\text { Prionocyclus macombi * } \\
\text { Prionocyclus hyatti * } \\
\text { Prionocyclus percarinatus } \\
\text { Collignoniceras woollgari } \\
\text { Mammites nodosoides } \\
\text { Vascoceras birchbyi * } \\
\text { Pseudaspidoceras flexuosum * } \\
\text { Watinoceras devonense } \\
\end{array}$ \\
\hline 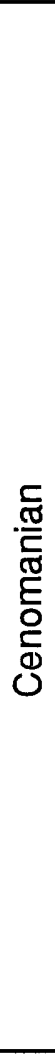 & $\begin{array}{l}\frac{0}{\mathrm{o}} \\
\frac{\mathrm{O}}{\varepsilon}\end{array}$ & $\begin{array}{l}52 \\
53 \\
54 \\
55 \\
56 \\
57 \\
58 \\
59 \\
60 \\
61 \\
62 \\
63 \\
64 \\
65 \\
66\end{array}$ & $\begin{array}{l}\text { Nigericeras scotti } \\
\text { Neocardioceras juddii * } \\
\text { Burroceras clydense } \\
\text { Euomphaloceras septemseriatum * } \\
\text { Vascoceras diartianum } \\
\text { Dunveganoceras conditum } \\
\text { Dunveganoceras albertense } \\
\text { Dunveganoceras problematicum } \\
\text { Dunveganoceras pondi * } \\
\text { Plesiacanthoceras wyomingense } \\
\text { Acanthoceras amphibolum * } \\
\text { Acanthoceras bellense } \\
\text { Acanthoceras muldoonense } \\
\text { Acanthoceras granerosense } \\
\text { Conlinoceras tarrantense * } \\
\quad \text { (Gap in biostratigraphic record) } \\
\text { Neogastroplites maclearni } \\
\text { Neogastroplites americanus } \\
\text { Neogastroplites muelleri } \\
\text { Neogastroplites cornutus * } \\
\text { Neogastroplites haasi * }\end{array}$ \\
\hline 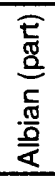 & $\begin{array}{l}\frac{\bar{g}}{3} \\
\frac{a}{3}\end{array}$ & $\begin{array}{l}72 \\
73\end{array}$ & $\begin{array}{l}\text { Inoceramus bellvuensis } \\
\text { Inoceramus comancheanus }\end{array}$ \\
\hline
\end{tabular}

*Fossil-zones dated radiometrically (Obradovich, 1993).

Figure 4. (continued) 
$10,000 \mathrm{ft}(3,050 \mathrm{~m})$ thick. The rock types and hiatuses in the section at Shotgun Butte differ from those in the sections at Red Desert and Kaycee (figs. 2 and 3), primarily as a function of distances between the three localities and the paleoshorelines and the thrust belt to the west. Near White River, South Dakota, on the craton and about 580 miles $(930 \mathrm{~km})$ east-northeast of Coalville, Cretaceous strata are about $3,000 \mathrm{ft}(915 \mathrm{~m})$ thick and are composed of siliciclastic and carbonate rocks that accumulated on a shelf mostly in nearshore and offshore marine environments.

At least four regional marine transgressions are recorded by strata in the transect (fig. 3). The first and oldest major transgression is represented by the Skull Creek Shale and a laterally equivalent part of the Thermopolis Shale (fig. 3); the second by the Greenhorn Formation and laterally equivalent beds in the Frontier Formation; the third includes the Niobrara Formation and strata of the same age in the Cody, Baxter, and Hilliard Shales; and the fourth and youngest by the Lewis Shale near Kaycee and Red Desert (fig. 3).

Many of the stratigraphic units in the transect are separated from underlying or overlying units by unconformities (figs. 2 and 3), which were formed by erosion during one or more of the following: lowering of sea level, regional or local tectonic uplift, and changes in the sediment supply or the climate. Major regional unconformities are recognized at the base, within, and near the top of the Lower Cretaceous sections at most of the localities. The hiatus at the base of the Cretaceous along the transect (fig. 3) might correspond in age to one or more of the medium type- 2 sequence boundaries illustrated by Haq and others (1987). The unconformity at the base of the Fall River Sandstone and laterally equivalent beds in the Cloverly Formation might be the same age as a major type-1 sequence boundary shown by Haq and others (1987). Van Wagoner and others (1990) concluded that the widespread unconformity at the base of the Muddy Sandstone Member of the Thermopolis Shale (figs. 2 and 3) is a type-1 sequence boundary. Upper Cretaceous strata of Turonian age generally contain one or two unconformities, which apparently are also type-1 sequence boundaries. In the eastern part of the transect near Red Bird and White River, an unconformity separates Turonian shale from Coniacian calcareous rocks (perhaps a minor sequence boundary), and a younger unconformity separates marine shales of early and middle Campanian ages. The unconformity between the Gammon Member and the overlying Sharon Springs Member of the Pierre Shale at Red Bird and White River is a type-1 sequence boundary (Van Wagoner and others, 1990). In the western part of the transect, an unconformity of middle Campanian age was found near Dutch John and an upper Campanian unconformity extends from Coalville eastward at least to Red Bird. The latter two unconformities could be type-1 sequence boundaries according to Haq and others (1987) and Van Wagoner and others (1990), respectively.

The Cretaceous System (65.4-142 Ma; Obradovich, 1993) is represented along the transect by sedimentary rocks and associated unconformities (figs. 2 and 3), although less conspicuous unconformities are not always depicted. In the region of Coalville, Church Butte, Dutch John, and Shotgun Butte, where Cretaceous deformation was substantial, less than 40 percent of Cretaceous time is represented by the strata; the remainder of the Cretaceous is represented by the hiatuses (fig. 3). The lithologic record of the System is least complete at Church Butte, on the Moxa Arch, where rocks probably represent only about 20 percent of Cretaceous time. This anomalous section indicates uplift and erosion in the area of the arch, perhaps beginning in early Turonian time and probably extending through most of late Campanian time. At Red Desert, Kaycee, Red Bird, and White River, about half of the System is recorded by strata. Upper parts of the Cretaceous sections at Kaycee and Red Bird, in contrast to the other localities, were not truncated by Tertiary erosion. Nevertheless, the most complete lithologic record of the Cretaceous along the transect is interpreted to be located on the craton near White River, where rocks represent slightly more than 50 percent of the period. The contrasting stratigraphic records of deposition at the eight localities apparently reflect differences in the amounts and effects of local tectonism as well as the effects of eustasy.

Chronohorizons defined by biozones within the transect (figs. 2 and 3) delimit four chronostratigraphic units. The oldest chronohorizon (biozone 62) also serves as an upper boundary for strata of Aptian, Albian, and early and middle Cenomanian ages. The youngest chronohorizon (biozone 9 ) is the lower boundary for rocks of latest Campanian and Maastrichtian ages. Stratigraphic units of Aptian age through most of the middle Cenomanian, middle Cenomanian to middle Coniacian age (biozones 62 to 37), and late Coniacian and Santonian age (biozones 37 to 30) are thickest near Coalville, at the western end of the transect. However, the thickness of the rocks of late Coniacian and Santonian ages at Coalville is only slightly more than their thickness at Dutch John, which is about $93 \mathrm{mi}(150 \mathrm{~km})$ east of Coalville and $43 \mathrm{mi}(69 \mathrm{~km})$ southeast of Church Butte on the Moxa Arch. The unit, mainly of early Campanian age (biozones 30 to 23), and the overlying unit of middle and late Campanian ages (biozones 23 to 9) are thickest at Red Desert, which is about $180 \mathrm{mi}(290 \mathrm{~km})$ east-northeast of Coalville. Strata of latest Campanian and Maastrichtian ages have been truncated at six of the eight localities, which precludes identification of the thickest part of the unit. Nevertheless, the geographic location of the maximum thickness of each chronostratigraphic unit suggests that the main depocenter along the transect moved progressively eastward during Cretaceous time. 
This movement might be related to the eastward movement of thrust plates in the thrust belt during the Cretaceous.

\section{ACKNOWLEDGMENTS}

The report by Dyman and others (1994) for the WIK was derived from information contributed by volunteers, including earth-scientists employed by governmental agencies and commercial organizations. Most of the contributors for Transect B-B' obtained data from unpublished records as well as from publications indicated in the attached list of references. Authors of the report for this transect supplied information for seven of the eight constituent localities. Strata at outcrops and in boreholes near Coalville were described by T.A. Ryer, The ARIES Group, Inc. Information concerning rocks in the subsurface near Church Butte was provided by R.E. Mueller, North American Resources Co. D.P. Stilwell, U.S. Bureau of Land Management, and A.C. Smith, Computational Geology, Inc., supplied data for beds at outcrops and in the subsurface near Dutch John. Information concerning strata in the subsurface near Red Desert was assembled by J.C. Dolson and W.B. Hanson, Amoco Production Co., and B.E. Law, U.S. Geological Survey. Outcrops at Shotgun Butte were described by W.R. Keefer (Keefer and Troyer, 1957), U.S. Geological Survey. Descriptions of outcropping beds near Kaycee were compiled by E.A. Merewether, U.S. Geological Survey. Information from outcrops in the vicinity of Red Bird was contributed by D.M. Wheeler, Ensign Oil \& Gas, Inc. At the eastern end of the transect near White River, strata at outcrops were studied by J.R. Gill and W.A. Cobban (1966), and rocks in the subsurface were interpreted and depicted by D.D. Rice (1977).

The authors of this report were assisted in gathering and presenting data for several of the localities by the following associates: Ramsey Bentley (Dutch John), S.R. Clawson (Church Butte), P.E. Devine of the Apache Corp. (Red Bird), and V.L. Leighton of Amoco Production Co. (Red Desert). Their important contributions through the preparation of relevant data are gratefully acknowledged. Thoughtful reviews of this report were provided by T.S. Dyman and R.C. Johnson of the U.S. Geological Survey and by R.J. Weimer, Professor Emeritus, Colorado School of Mines. Their knowledgeable comments and valuable suggestions led to improvements in the report and are greatly appreciated.

Molluscan fossils from outcrops of marine beds at the preceding localities (fig. 1) and many other localities in the Western Interior have been identified and assigned ages by W.A. Cobban (Cobban and Reeside, 1952; Cobban and others, 1994). Palynomorphs in nonmarine and nearshore-marine rocks at outcrops and in boreholes in western Wyoming and adjacent areas have been described and related to the molluscan fossils by Nichols and Jacobson (1982a), Nichols and others (1982b), and Nichols (1994). Absolute ages for Cretaceous strata in the Rocky Mountains and Great Plains were determined by J.D. Obradovich $(1993,1996)$ by means of radiometric analyses of sanidine-bearing bentonite from outcropping beds and drill-cores that are associated with fossiliferous beds. The geochronological information developed and provided by the earthscientists named above was essential in the preparation of figures 2,3 , and 4 .

\section{SELECTED REFERENCES}

(References used in compiling profiles or cited in text)

Bader, J.W., Gill, J.R., Cobban, W.A., and Law, B.E., 1983, Biostratigraphic correlation chart of some Upper Cretaceous rocks from the Lost Soldier area, Wyoming to west of Craig, Colorado: U.S. Geological Survey Miscellaneous Field Studies Map-1548.

Bader, J.W., Law, B.E., and Spencer, C.W., 1982, Preliminary chart showing electric log correlation, Section D-D', of some Upper Cretaceous and Tertiary rocks, Green River Basin, Wyoming: U.S. Geological Survey Open-File Report 82-129.

Berg, R.L., 1975, Depositional environment of Upper Cretaceous Sussex Sandstone, House Creek field, Wyoming: American Association of Petroeum Geologists Bulletin, v. 59, p. 2099-2110.

Bradley, M.D., 1988, Structural evolution of the Uinta Mountains, Utah, and their interaction with the UtahWyoming salient of the Sevier overthrust belt: unpublished Ph.D. dissertation, University of Utah, Salt Lake City, 193 p.

Brenner, R.L., 1978, Sussex Sandstone of Wyoming--example of Cretaceous offshore sedimentation: American Association of Petroleum Geologists Bulletin, v. 62, p. 181-200.

Bucurel, H.G., 1981, Subsurface correlations of some Upper Cretaceous and Tertiary rocks, Great Divide basin, Wyoming, Section A-A': U.S. Geological Survey Open-File Report 81-981.

Bucurel, H.G., 1982, Section B-B', subsurface correlations of some Upper Cretaceous and Tertiary rocks, Great Divide Basin, Wyoming: U.S. Geological Survey Open-File Report 82-456. 
Bucurel-White, Hildie, 1983, Section C-C', surface and subsurface correlations of some Upper Cretaceous and Tertiary rocks from the northeast flank Rock Springs uplift to the Rawlins uplift, Great Divide Basin, Wyoming: U.S. Geological Survey Open-File Report 83-418.

Byers, C.W., and Larson, D.W., 1979, Paleoenvironments of Mowry Shale (Lower Cretaceous), western and central Wyoming: American Association of Petroleum Geologists Bulletin, v. 63, p. 354-375.

Cobban, W.A., 1993, Diversity and distribution of Late Cretaceous ammonites, Western Interior, United States, in Caldwell, W.G.E., and Kauffman, E.G., eds., Evolution of the Western Interior basin: Geological Association of Canada Special Paper 39, p. 435-451.

Cobban, W.A., Merewether, E.A., Fouch, T.D., and Obradovich, J.D., 1994, Some Cretaceous shorelines in the Western Interior of the United States, in Caputo, M.V., Peterson, J.A., and Franczyk, K.J., eds., Mesozoic Systems of the Rocky Mountain Region, USA: Society of Economic Paleontologists and Mineralogists (Society for Sedimentary Geology), Rocky Mountain Section, p. 393-414.

Cobban, W.A., and Reeside, J.B., Jr., 1952, Frontier Formation, Wyoming and adjacent areas: American Association of Petroleum Geologists Bulletin, v. 36, p. 1913-1961.

Connor, C.W., 1992, The Lance Formation--petrography and stratigraphy, Powder River Basin and nearby basins, Wyoming and Montana: U.S. Geological Survey Bulletin 1917-I, 17 p.

Crittenden, M.D., Jr., 1974, Regional extent and age of thrust near Rockport Reservoir and relation to possible exploration targets in northern Utah: American Association of Petroleum Geologists Bulletin, v. 58, p. 2428-2435.

Curry, W.H., III, 1976, Late Cretaceous Teapot delta of southern Powder River Basin, Wyoming, in Laudon, R.B., Curry, W.H., III, and Runge, J.S., eds., Geology and energy resources of the Powder River: Wyoming Geological Association, 28th Annual Field Conference., 1976, Guidebook, p. 21-28.

DeCelles, P.G., 1988, Lithologic provenance modeling applied to the Late Cretaceous synorogenic Echo Canyon Conglomerate, Utah: A case of multiple source areas: Geology, v. 16, p. 1039-1043.

Doelling, H.H., and Graham, R.L., 1972, Eastern and northern Utah coal fields: Vernal, Henry Mountains, Sego, La Sal-San Juan, Tabby Mountain, Coalville, Henrys Fork, Goose Creek, and Lost Creek: Utah Geological and Mineral Survey Monograph Series, no. 2, 409 p.

Dogan, U.D., 1984, Stratigraphy, petrology, depositional and post-depositional histories and their effects upon reservoir properties of the Parkman Formation of the Mesaverde Group, Powder River Basin, Wyoming: Ph.D. thesis, University of Iowa, Iowa City, 265 p.

Dorf, Erling, 1942, Flora of the Lance Formation at its type locality, Niobrara County, Wyoming, part 2 of Upper Cretaceous flora of the Rocky Mountain region: Carnegie Institute of Washington, Publication 508, p. 70-159.

Dyman, T.S., Merewether, E.A., Molenaar, C.M., Cobban, W.A., Obradovich, J.D., Weimer, R.J., and Bryant, W.A., 1994, Stratigraphic transects for Cretaceous rocks, Rocky Mountains and Great Plains regions, in Caputo, M.V., Peterson, J.A., and Franczyk, K.J., eds., Mesozoic Systems of the Rocky Mountain Region, USA: Society of Economic Paleontologists and Mineralogists (Society for Sedimentary Geology), Rocky Mountain Section, p. 365-391.

Dyman, T.S., Porter, K.W., Tysdal, R.G., Cobban, W.A., Fox, J.E., Hammond, R.H., Nichols, D.J., Perry, W.J., Jr., Rice, D.D., Setterholm, D.R., Shurr, G.W., Haley, J.C., Lane, D.E., Anderson, S.B., and Campen, E.B., 1995, West-east stratigraphic transect of Cretaceous rocks in the northern Rocky Mountains and Great Plains Regions, southwestern Montana to southwestern Minnesota: U.S. Geological Survey Miscellaneous Investigations Map I-2474-A.Eardley, A.J., 1944, Geology of the north-central Wasatch Mountains, Utah: Geological Society of America Bulletin, v. 55, p. 819-894.

Engelmann, H., 1876, Geological report, in Simpson, J.H., Report on exploration across the Great Basin of the Territory of Utah: Washington, D.C., Government Printing Office, p. 247-338.

Fox, J.E., and Higley, D.K., 1987, Thickness of the Upper Cretaceous Niobrara Formation, Powder River Basin, Wyoming and Montana: U.S. Geological Survey Open-File Report 87-340J.

Garing, J.D., and Tainter, P.A., 1985, Greater Green River Basin regional seismic line, in Seismic exploration of the Rocky Mountain region: Rocky Mountain Association of Geologists and Denver Geophysical Society, p. 233-238.

Gill, J.R., and Burkholder, R.E., 1979, Measured sections of the Montana Group and equivalent rocks from Montana and Wyoming: U.S. Geological Survey Open-File Report 79-1143, 202 p.

Gill, J.R., and Cobban, W.A., 1966, The Red Bird section of the Upper Cretaceous Pierre Shale in Wyoming, with a section on A new Echinoid from the Cretaceous Pierre Shale of eastern Wyoming, by P.M. Kier: U.S. Geological Survey Professional Paper 393-A, p. A1-A73. 
Gill, J.R., and Cobban, W.A., 1973, Stratigraphy and geologic history of the Montana Group and equivalent rocks, Montana, Wyoming, and North and South Dakota: U.S. Geological Survey Professional Paper 776, $37 \mathrm{p}$.

Gill, J.R., Merewether, E.A., and Cobban, W.A., 1970, Stratigraphy and nomenclature of some Upper Cretaceous and lower Tertiary rocks in south-central Wyoming: U.S. Geological Survey Professional Paper 667, $53 \mathrm{p}$.

Hale, L.A., 1950, Stratigraphy of the Upper Cretaceous Montana Group in the Rock Springs Uplift, Sweetwater County, Wyoming, in Southwest Wyoming: Wyoming Geological Association, 5th Annual Field Conference, 1950, Guidebook, p. 49-58.

Hale, L.A., 1959, Intertonguing Upper Cretaceous sediments of northeastern Utah-northwestern Colorado: Rocky Mountain Association of Geologists, 11 th Annual Field Conference, 1959, Guidebook, p. 55-66.

Hale, L.A., 1960, Frontier Formation--Coalville, Utah and nearby areas of Wyoming and Colorado, in Overthrust belt of southwestern Wyoming and adjacent areas: Wyoming Geological Association, 15th Annual Field Conference, 1960, Guidebook, p. 137-146.

Hale, L.A., and Van DeGraff, F.R., 1964, Cretaceous stratigraphy and facies patterns--northeastern Utah and adjacent areas: Intermountain Association of Petroleum Geologists, 13th Annual Field Conference, 1964, Guidebook, p. 115-138.

Hansen, W.R., 1965, Geology of the Flaming Gorge area, Utah-Colorado-Wyoming: U.S. Geological Survey Professional Paper 490, 196 p.

Hansley, P.L., and Whitney, C.G., 1990, Petrology, diagenesis, and sedimentology of oil reservoirs in Upper Cretaceous Shannon Sandstone Beds, Powder River Basin, Wyoming: U.S. Geological Survey Bulletin 1917-C, p. C1-C31.

Haq, B.U., Hardenbol, Jan, and Vail, P.R., 1987, Chronology of fluctuating sea levels since the Triassic: Science, v. 235, p. 1156-1167.

Jacobson, S.R., and Nichols, D.J., 1982, Palynological dating of syntectonic units in the Utah-Wyoming Thrust Belt: the Evanston Formation, Echo Canyon Conglomerate, and Little Muddy Creek Conglomerate, in Powers, R.B., ed., Geologic studies of the Cordilleran Thrust Belt: Rocky Mountain Association of Geologists, Denver, Colorado, v. 2, p. 735-750.

Keefer, W.R., and Troyer, M.L., 1957, Geology of the Shotgun Butte area, Fremont County, Wyoming: U.S. Geological Survey Bulletin 1157, 123 p.

Kirschbaum, M.A., 1985, Stratigraphic cross section showing depositional environments of Upper Cretaceous and Paleocene coal-bearing rocks in the Kappes Canyon Quadrangle, Sweetwater County, Wyoming: U.S. Geological Survey Miscellaneous Field Studies Map MF-1769.

Kirschbaum, M.A., 1986, Geologic map of the Kappes Canyon Quadrangle, Sweetwater County, Wyoming: U.S. Geological Survey Geologic Quadrangle Map GQ-1607.

Law, B.E., 1979, Section B-B', Subsurface and surface correlations of some Upper Cretaceous and Tertiary rocks, northern Green River Basin, Wyoming: U.S. Geological Survey Open-File Report 79-1689, 2 plates.

Law, B.E., and Johnson, R.C., 1990, Structural and stratigraphic framework of the Pinedale Anticline, Wyoming, and the Multiwell Experiment site, Colorado, in Law, B.E., and Spencer, C.W., eds., Geology of tight gas reservoirs in the Pinedale anticline area, Wyoming, and at the Multiwell Experiment site, Colorado: U.S. Geological Survey Bulletin 1886-B, p. B1-B11.

Law, B.E., Spencer, C.W., and Roehler, H.W., 1979, Section A-A', surface and subsurface correlations of some Upper Cretaceous and Tertiary rocks, Green River Basin, Wyoming: U.S. Geological Survey Open-File Report 79-0357, 2 sheets.

Lawrence, D.T., 1982, Influence of transgressive-regressive pulses on coal-bearing strata of the Upper Cretaceous Adaville Formation, southwestern Wyoming: Utah Geological and Mineral Survey, Bulletin 118 , p. 32-49.

Markochick, D.J., Law, B.E., and Spencer, C.W., 1982, Section E-E', preliminary subsurface correlations of some Cretaceous and Tertiary rocks, from Moxa Arch to Rock Springs Uplift, Green River Basin, Wyoming: U.S. Geological Survey Open-File Report 82-0455, 2 sheets.

Mathews, A.A.L., 1931, Mesozoic stratigraphy of the central Wasatch Mountains: Oberlin College Laboratory Bulletin, new series, no.1, p. 1-50.

McGookey, D.P., compiler, 1972, Cretaceous System, in Mallory, W.W., editor-in-chief, Geological atlas of the Rocky Mountain region: Rocky Mountain Association of Geologists, Denver, Colorado, p. 190-211.

Meek, F.V., 1873, Paleontological report: U.S. Geological Survey of the Territories, 6th Annual Report, p. 429-518.

Merewether, E.A., 1972, Geologic map of the Rawlins NW quadrangle, Carbon County, Wyoming: U.S. Geological Survey Geologic Quadrangle Map GQ-1010. 
Merewether, E.A., 1983, The Frontier Formation and mid-Cretaceous orogeny in the foreland of southwestern Wyoming: The Mountain Geologist, v. 20, no. 4, p. 121-138.

Merewether, E.A., 1990, Cretaceous formations of the Hanna basin, south-central Wyoming [abs.]: American Association of Petroleum Geologists Bulletin, v. 74, p.1337.

Merewether, E.A., Blackmon, P.D., and Webb, J.C., 1984, The mid-Cretaceous Frontier Formation near the Moxa arch, southwestern Wyoming: U.S. Geological Survey Professional Paper 1290, 29 p.

Merewether, E.A., and Cobban, W.A., 1986, Biostratigraphic units and tectonism in the mid-Cretaceous foreland of Wyoming, Colorado, and adjoining areas, in Peterson, J.A., ed., Paleotectonics and sedimentation in the Rocky Mountain region, United States: American Association of Petroleum Geologists Memoir 41, p. 443-468.

Merewether, E.A., Cobban, W.A., and Spencer, C.W., 1976, The Upper Cretaceous Frontier Formation in the Kaycee-Tisdale Mountain area, Johnson County, Wyoming, in Laudon, R.B., Curry, W.H., III, and Runge, J.S., eds., Geology and energy resources of the Powder River: Wyoming Geological Association, 28th Annual Field Conference, 1976, Guidebook, p. 33-44.

Mirsky, Arthur, 1962, Stratigraphic sections of Upper Jurassic and Lower Cretaceous rocks in the southern Bighorn Mountains, Wyoming: Geological Survey of Wyoming Report of Investigations no. 8, $33 \mathrm{p}$.

Molenaar, C.M., and Wilson, B.W., 1990, The Frontier Formation and associated rocks of northeastern Utah and northwestern Colorado: U.S. Geological Survey Bulletin 1787-M, 21 p.

Mullens, T.E., 1971, Reconnaissance study of the Wasatch, Evanston, and Echo Canyon Formations in part of northern Utah: U.S. Geological Survey Bulletin 1311-D, 31 p.

Myers, R.C., 1977, Stratigraphy of the Frontier Formation (Upper Cretaceous), Kemmerer area, Lincoln County, Wyoming, in Rocky Mountain thrust belt geology and resources: Wyoming Geological Association, 29th Annual Field Conference, 1977, Guidebook, p. 271-311.

Nichols, D.J., 1994, A revised palynostratigraphic zonation of the nonmarine Upper Cretaceous, Rocky Mountain region, United States, in Caputo, M.V., Peterson, J.A., and Franczyk, K.J., eds., Mesozoic Systems of the Rocky Mountain Region, USA: Society of Economic Paleontologists and Mineralogists (Society for Sedimentary Geology), Rocky Mountain Section, p. 503-522.

Nichols, D.J., and Jacobson, S.R., 1982a, Cretaceous biostratigraphy in the Wyoming Thrust Belt: The Mountain Geologist, v. 19, no. 3, p. 73-78.

Nichols, D.J., Jacobson, S.R., and Tschudy, R.H., 1982b, Cretaceous palynomorph biozones for the central and northern Rocky Mountain region of the U.S., in Powers, R.B., ed., Geologic studies of the Cordilleran Thrust Belt: Rocky Mountain Association of Geologists, p. 73-78.

Nixon, R.P., 1973, Oil source beds in Cretaceous Mowry Shale of northwestern interior United States: American Association of Petroleum Geologists Bulletin, v. 57, p. 136-161.

Obradovich, J.D., 1993, A Cretaceous time-scale, in Caldwell, W.G.E., and Kauffman, E.G., eds., Evolution of the Western Interior Basin: Geological Association of Canada Special Paper 39, p. 379-396.

Obradovich, J.D., and Cobban, W.A., 1975, A time-scale for the Late Cretaceous of the Western Interior of North America, in Caldwell, W.G.E., ed., The Cretaceous System in the Western Interior of North America: Geological Association of Canada Special Paper 13, p. 31-54.

Obradovich, J.D., Cobban, W.A., Merewether, E.A., and Weimer, R.J., 1996, A time framework for the late Albian and early Cenomanian strata of northern Wyoming and Montana: Geological Society of America Abstracts with Programs, 1996 Annual Meeting, Denver, Colorado, p. A-66.

Perman, R.C., 1990, Depositional history of the Maastrichtian Lewis Shale in south-central Wyoming: deltaic and interdeltaic, marginal marine through deep-water marine, environments: American Association of Petroleum Geologists Bulletin, v. 74, p.1695-1717.

Peterson, R.H., Gauger, D.J., and Lankford, R.R., 1953, Microfossils of the Upper Cretaceous of northeastern Utah and southwestern Wyoming: Utah Geological and Mineral Survey Bulletin 47, 158 p.

Roehler, H.W., 1978, Correlations of coal beds in the Fort Union, Almond, and Rock Springs Formations in measured sections on the west flank of the Rock Springs Uplift, Sweetwater County, Wyoming: U.S. Geological Survey Open-File Report 78-0395, 1 sheet.

Roehler, H.W., 1983, Stratigraphy of Upper Cretaceous and lower Tertiary outcrops in the Rock Springs uplift, Wyoming: U.S. Geological Survey Miscellaneous Investigations Map I-1500.

Roehler, H.W., 1989, Surface-subsurface correlations of the Mesaverde Group and associated Upper Cretaceous formations, Rock Springs to Atlantic Rim, southwest Wyoming: U.S. Geological Survey Miscellaneous Field Studies Map MF-2078.

Roehler, H.W., and Phillips, S.T., 1980, Cross section of the Rock Springs and Blair Formations in measured sections in the Flaming Gorge-Minnies Gap-Clay basin area, Utah and Wyoming: Miscellaneous Field Studies Map MF-1216. 
RPI International, Inc., 1988, Powder River Basin DISC; Digital stratigraphic datafile of correlation from 30,000 wells in the Powder River Basin, Wyoming: unpublished.

Ryer, T.A., 1976, Cretaceous invertebrate faunal assemblages of the Frontier and Aspen Formations, Coalville and Rockport areas, north-central Utah: The Mountain Geologist, v. 13, no. 3, p. 101-114.

Ryer, T.A., 1976, Cretaceous stratigraphy of the Coalville and Rockport areas, Utah: Utah Geology, v. 3, p. 71-83.

Ryer, T.A., 1977, Age of Frontier Formation in north-central Utah: American Association of Petroleum Geologists Bulletin, v. 61, p. 112-116.

Ryer, T.A., 1977, Patterns of Cretaceous shallow-marine sedimentation, Coalville and Rockport areas, Utah: Geological Society of America Bulletin, v. 88, p. 177-188.

Schmitt, J.G., 1985, Synorogenic sedimentation of Upper Cretaceous Frontier Formation conglomerates and associated strata, Wyoming-Idaho-Utah thrust belt: The Mountain Geologist, v. 22, p. 5-16.

Smith, J.H., 1961, A summary of stratigraphy and paleontology, upper Colorado and Montanan Groups, southcentral Wyoming, northeastern Utah, and northwestern Colorado, in Wiloth, G.J., ed., Symposium on Late Cretaceous rocks, Wyoming and adjacent areas: Wyoming Geological Association, 16th Annual Field Conference, 1961, Guidebook, p. 101-112.

Smith, J.H., 1965, A summary of stratigraphy and paleontology, upper Colorado and Montanon Groups, southcentral Wyoming, northeastern Utah, and northwestern Colorado, in DeVoto, R.H., Bitter, R.K., and Austin, A.C., eds., Sedimentation of Late Cretaceous and Tertiary outcrops, Rock Springs uplift: Wyoming Geological Association, 19th Field Conference, 1965, Guidebook, p. 13-26.

Spearing, D.R., 1976, Upper Cretaceous Shannon Sandstone: an offshore, shallow-marine sand body, in Laudon, R.B., Curry, W.H., III, and Runge, J.S., eds., Geology and energy resources of the Powder River: Wyoming Geological Association, 28th Annual Field Conference, 1976, Guidebook, p. 65-72.

Stanton, T.W., 1893, The Colorado Formation and its invertebrate fauna: U.S. Geological Survey Bulletin 106, $288 \mathrm{p}$.

Stokes, W.L., and Madsen, J.H., Jr., compilers, 1961, Geological map of Utah: Utah Geological and Mineral Survey, scale 1:250,000, in four quarters.

Tillman, R.W., and Almon, W.R., 1979, Diagenesis of Frontier Formation offshore bar sandstones, Spearhead Ranch Field, Wyoming, in Scholle, P.A., and Schluger, P.R., eds., Aspects of diagenesis: Society of Economic Paleontologists and Mineralogists Special Publication No. 26, p. 337-378.

Tillman, R.W., and Martinsen, R.S., 1984, The Shannon shelf-ridge sandstone complex, Salt Creek anticline area, Powder River basin, Wyoming, in Tillman, R.W., and Siemers, C.T., eds., Siliciclastic shelf sediments: Society of Economic Paleontologists and Mineralogists Special Publication No. 34, p. 85-142.

Trexler, D.W., 1966, Stratigraphy and structure of the Coalville area, Utah: Professional Contribution no. 2, Colorado School of Mines, Golden, Colorado, $69 \mathrm{p}$.

Tyler, T.F., 1978, Preliminary chart showing electric log correlation section B-B' of some Upper Cretaceous and Tertiary rocks, Washakie basin, Wyoming: U.S. Geological Survey Open-File Report 78-1053.

Tyler, T.F., 1979, Preliminary chart showing electric log correlation section D-D' of some Upper Cretaceous and Tertiary rocks, Rock Springs uplift, Wyoming: U.S. Geological Survey Open-File Report 79-1217.

Tyler, T.F., 1979, Preliminary chart showing electric log correlation section F-F' of some Upper Cretaceous and Tertiary rocks, east flank Rock Springs uplift, Wyoming: U.S. Geological Survey Open-File Report 79-1573.

Van Wagoner, J.C., Mitchum, R.M., Campion, K.M., and Rahmanian, V.D., 1990, Siliciclastic sequence stratigraphy in well logs, cores, and outcrops--Concepts for high-resolution correlation of time and facies: American Association of Petroleum Geologists Methods in Exploration Series, no. 7, 55 p.

Wegemann, C.H., 1915, The Coalville coal field, Utah: U.S. Geological Survey Bulletin 581-E, p. 161-183.

Williams, N.C., and Madsen, J.H., Jr., 1959, Late Cretaceous stratigraphy of the Coalville area, Utah: Intermountain Association of Petroleum Geologists, 10th Annual Field Conference, 1959, Guidebook, p. $122-125$. 
